Case Report

\title{
Primary Acinic Cell Carcinoma of the Breast: A Clinicopathological and Immunohistochemical Study
}

\author{
Kiyoshi Shingu, Tokiko Ito, Gengo Kaneko, and Nobuo Itoh \\ Departments of Surgery and Pathology, Iida Municipal Hospital, 438 Yawatacho, Iida, Nagano 395-8502, Japan \\ Correspondence should be addressed to Kiyoshi Shingu; 0374@imh.jp
}

Received 4 August 2013; Accepted 28 August 2013

Academic Editors: S. Aksoy and K. Aogi

Copyright (C) 2013 Kiyoshi Shingu et al. This is an open access article distributed under the Creative Commons Attribution License, which permits unrestricted use, distribution, and reproduction in any medium, provided the original work is properly cited.

\begin{abstract}
Acinic cell carcinoma of the breast is an extremely rare, malignant neoplasm characterized by widespread acinar cell-like differentiation and clinically low-grade malignancy. Herein, we report a case of acinic cell carcinoma of the breast in a 41-yearold woman. The tumor was poorly demarcated but had a firm consistency. It was removed with lumpectomy, and sentinel lymph node biopsy was performed to check for metastasis. Microscopically, the tumor showed an infiltrative growth pattern with a combination of solid, trabecular, and microglandular areas. Many of the tumor cells had abundant clear vacuolated cytoplasm containing zymogen-typed granules which resemble acinar cells of the salivary glands. The immunohistochemical profile of the tumor was also similar to that of salivary gland acinic cell carcinoma: the tumor cells were positive for amylase, lysozyme, $\alpha$-1antichymotrypsin, S-100 protein, and epithelial membrane antigen and negative for estrogen receptor, progesterone receptor, and human epidermal growth factor receptor 2. She received postoperative chemoradiation therapy and has been well for 3 years since surgery. As studies on large series are lacking, further studies are needed to elucidate the biological characteristics of acinic cell carcinoma of the breast.
\end{abstract}

\section{Introduction}

Acinic cell carcinomas (ACCs) of the breast are similar to tumors that occur in the salivary glands and show acinic cell differentiation. This tumor type was first described in 1996 by Roncaroli et al. [1], and since then, several such cases have been reported [2-10]. Although it is an extremely rare tumor, its histological, immunohistochemical, and, ultrastructural characteristics have been described in previous reports [210]. Herein, we report a case of pure acinic cell carcinoma of the breast in a 41-year-old Japanese woman and review the English literature we could obtain.

\section{Case Report}

A 41-year-old Japanese woman who had a mass in her left breast was admitted to our hospital for further assessment. Physical examination revealed an irregular mass in the lateral upper quadrant of the left breast, approximately $2.5 \mathrm{~cm}$ in diameter. No dimpling or palpable axillary and supraclavicular lymph nodes were detected. Results of laboratory tests were all within the reference range. Mammography revealed a focal asymmetric density in the lateral upper quadrant of the left breast (Figure 1), and ultrasonography showed a heterogeneous hypoechoic mass with an ill-defined margin, measuring $3.4 \times 1.1 \times 3.0 \mathrm{~cm}$ (Figure 2). Enhanced magnetic resonance imaging (MRI) revealed a mass of high intensity, but no intraductal spread was detected (Figure 3). Further examinations, including computed tomography of the thorax and abdomen and bone scintigraphy, showed no signs of metastatic lesions. Fine-needle aspiration cytology revealed malignancy, suggesting invasive ductal carcinoma.

The case was diagnosed as T2N0M0, stage IIA breast cancer, and lumpectomy and sentinel lymph node biopsy were therefore performed. Grossly, the specimen revealed a $3.5 \times 3.0 \times 2.0 \mathrm{~cm}$, white-yellow-colored tumor with an ill-defined border and a rubbery consistency. Histologically, the tumor cells had round-to-oval, displaced nuclei with a striking single nucleolus and clear cytoplasm, many of which contained large, coarse, and bright red granules resembling zymogen granules of the acinar cells of the 


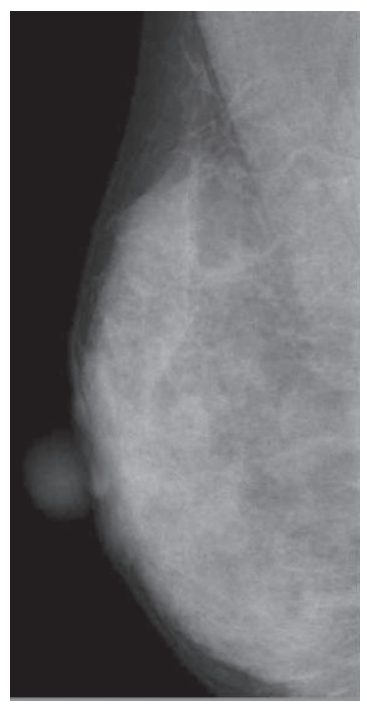

(a)

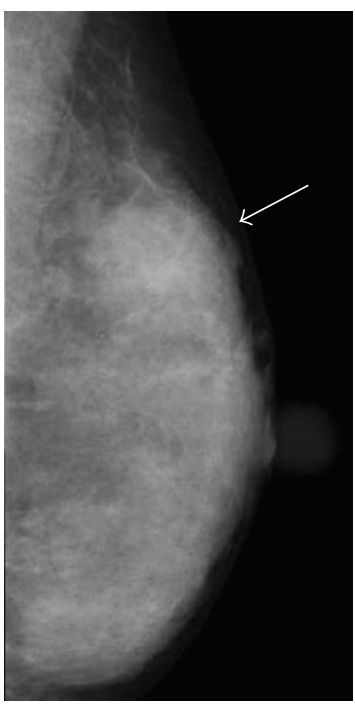

(b)
FIGURE 1: Mammography revealed a focal asymmetric density (arrow) in the lateral upper quadrant of the left breast.

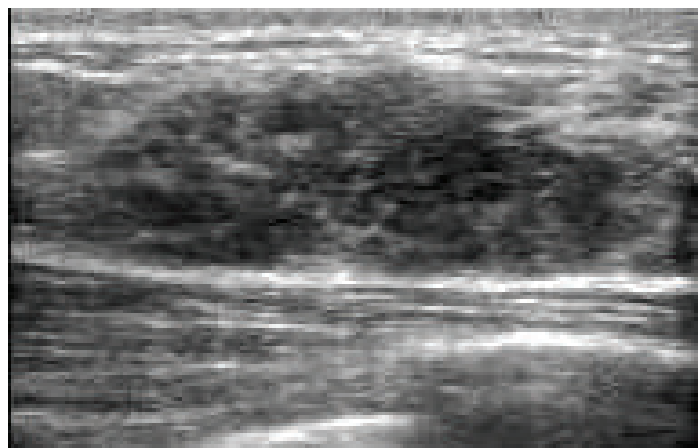

FIGURE 2: Ultrasonography showed a heterogeneous hypoechoic mass with an ill-defined margin, measuring $3.4 \times 1.1 \times 3.0 \mathrm{~cm}$.

salivary gland. They showed an infiltrating growth pattern with a combination of solid, trabecular, and microglandular features (Figure 4). The nuclear grade of the tumor cells was determined to be grade 2. Lymphatic permeation was occasionally seen, but the sentinel lymph node was free of metastasis.

Immunohistochemically, most of the tumor cells stained strongly for amylase, lysozyme, $\alpha$-1-antichymotrypsin $(\alpha 1 \mathrm{ACT})$ (Figure 4$)$, epithelial membrane antigen (EMA), and S-100 protein and also showed positive for cytokeratin 7 and E-cadherin. Estrogen and progesterone receptors and human epidermal growth factor receptor 2 (HER2) protein were triple negative. From the above results we could interpret the tumor as acinic cell carcinoma of the breast.

Because the patient was diagnosed as having invasive breast cancer with a triple-negative phenotype, postoperative radiotherapy ( $50 \mathrm{~Gy}-/ 25$ fractions) followed by adjuvant chemotherapy (TC: docetaxel $75 \mathrm{mg} / \mathrm{m}^{2}$ and cyclophosphamide $600 \mathrm{mg} / \mathrm{m}^{2}$ administered intravenously every 3

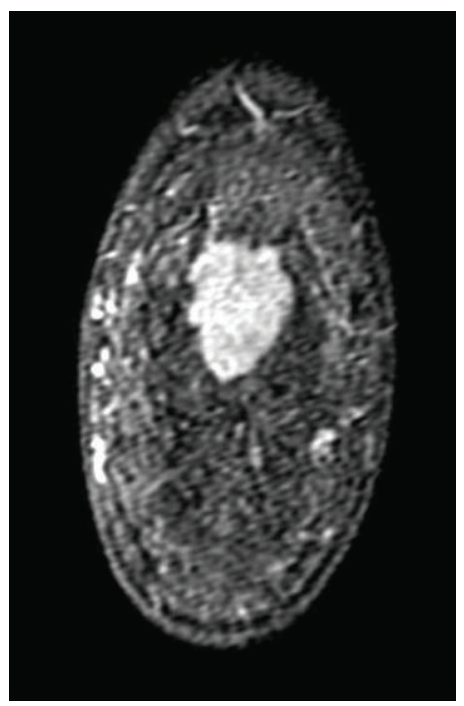

FIGURE 3: Enhanced MRI revealed a mass of high intensity, but no intraductal spread was detected (coronal section).

weeks for 4 cycles) was administered. Although the followup period to date has been short (3 years), there have thus far been no signs of recurrence.

\section{Discussion}

No more than 15 cases of ACC of the breast (including this case) have been reported since it was first described in 1996 as a rare variant of breast carcinoma showing morphological features resembling those of salivary glands [1]. These cases are summarized in Table 1. ACC of the breast affects women between 20 and 80 years of age (mean, 54.2 years; with a single case involving a male patient). It generally presents as a palpable nodule ranging from 2 to $6 \mathrm{~cm}$ in size although 1 case involved a nonpalpable mass that was only discovered by mammography [3]. Several studies have discussed the usefulness of diagnostic imagings for ACC, although their findings have sometimes differed [1, 2, 8-10]. For example, mammography showed a well-defined mass in some cases $[1,8,10]$ but no abnormal findings in another [9]. Ultrasonography revealed an intracystic tumor in only male patient yet described [2]. In our case, mammography revealed focal asymmetric density, and ultrasonographic findings resembled those of ductal carcinoma in situ. Thus, at present, it seems that there are no specific imaging findings that characterize this tumor type. Findings regarding tumor spread are similarly inconsistent. Lymph node metastasis was observed in 4 cases, and 3 cases showed nodal involvement upon recurrence with additional local, liver, and lung metastases. Only 1 patient died of the tumor, suggesting a relatively favorable prognosis for this tumor type although followup was limited to a maximum of 10 years [7].

As the breasts and the salivary glands are known to share many similarities with respect to embryology [11], ACC of the breast is similar to its salivary gland counterpart at the morphological, immunohistochemical, and ultrastructural 
TABLE 1: Clinical characteristics of acinic cell carcinoma of the breast.

\begin{tabular}{|c|c|c|c|c|c|c|c|c|c|}
\hline Nr. & References & Age (years) & Gender & $\begin{array}{c}\text { Tumor } \\
\text { size }(\mathrm{mm})\end{array}$ & $\begin{array}{c}\mathrm{LN} \\
\text { metastases }\end{array}$ & Operation & $\begin{array}{c}\text { Adjuvant } \\
\text { therapy }\end{array}$ & $\begin{array}{l}\text { Follow- } \\
\text { up (years) }\end{array}$ & Recurrence \\
\hline 1 & Roncaroli et al. [1] & 42 & $\mathrm{~F}$ & 30 & $1 / 18$ & $\mathrm{Bt}+\mathrm{Ax}$ & CT & 5 & - \\
\hline 2 & Shimao et al. [2] & 23 & M & 48 & - & $\mathrm{Bt}+\mathrm{Ax}$ & Not known & 2.8 & - \\
\hline 3 & Damiani et al. [3] & 35 & $\mathrm{~F}$ & 40 & $2 / 20$ & $\mathrm{Bt}+\mathrm{Ax}$ & CT & 1 & - \\
\hline 4 & {$[3]$} & 63 & $\mathrm{~F}$ & 50 & Not known & $\mathrm{BCS}$ & - & 4 & Local \\
\hline 5 & {$[3]$} & 55 & $\mathrm{~F}$ & 20 & Not known & $\mathrm{BCS}$ & - & Not known & Not known \\
\hline 6 & {$[3]$} & 64 & $\mathrm{~F}$ & 33 & $0 / 8$ & $\mathrm{BCS}+\mathrm{Ax}$ & - & 1 & - \\
\hline 7 & {$[3]$} & 80 & $\mathrm{~F}$ & 20 & Not known & BCS & $\mathrm{HT}$ & 1 & - \\
\hline 8 & Schmitt et al. [4] & 79 & $\mathrm{~F}$ & 45 & $0 / 23$ & $\mathrm{Bt}+\mathrm{Ax}$ & $\mathrm{RT}$ & 1.7 & - \\
\hline 9 & $\begin{array}{l}\text { Coyne and } \\
\text { Dervan [5] }\end{array}$ & 49 & $\mathrm{~F}$ & 20 & $2 / 11$ & $\mathrm{Bt}+\mathrm{Ax}$ & CT & 3 & Liver (died) \\
\hline 10 & Elster et al. [6] & 48 & $\mathrm{~F}$ & 30 & $0 / 6$ & $\mathrm{BCS}+\mathrm{Ax}$ & $\mathrm{CT}+\mathrm{RT}$ & Not known & Not known \\
\hline 11 & $\begin{array}{c}\text { Peintinger et al. } \\
\text { [7] }\end{array}$ & 36 & $\mathrm{~F}$ & 35 & $0 / 15$ & $\mathrm{BCS}+\mathrm{Ax}$ & $\mathrm{CT}+\mathrm{RT}$ & 10 & Lung \\
\hline 12 & $\begin{array}{c}\text { Tanahashi et al. } \\
{[8]}\end{array}$ & 80 & $\mathrm{~F}$ & 30 & - & $\mathrm{Bt}+\mathrm{SN}$ & Not known & 1.8 & - \\
\hline 13 & Chang et al. [9] & 39 & $\mathrm{~F}$ & 55 & $\begin{array}{c}\text { 1/Not } \\
\text { known }\end{array}$ & $\mathrm{BCS}+\mathrm{Ax}$ & Not known & Not known & Not known \\
\hline 14 & Choh et al. [10] & 79 & $\mathrm{~F}$ & 27 & - & $\mathrm{BCS}+\mathrm{SN}$ & RT & 0.8 & - \\
\hline 15 & Present case & 41 & $\mathrm{~F}$ & 25 & $0 / 1$ & $\mathrm{BCS}+\mathrm{SN}$ & $\mathrm{CT}+\mathrm{RT}$ & 3 & - \\
\hline
\end{tabular}

Bt: total mastectomy; BCS: breast-conserving surgery; Ax: axillary lymph nodes dissection; SN: sentinel lymph node biopsy; CT: chemotherapy; HT: hormone therapy; RT: radiotherapy.

TABLE 2: Immunohistochemical characteristics of acinic cell carcinoma of the breast.

\begin{tabular}{|c|c|c|c|c|c|c|c|c|c|}
\hline Nr. & References & Amylase & Lysozyme & $\alpha 1-\mathrm{ACT}$ & S-100 & EMA & ER & PgR & HER2 \\
\hline 1 & Roncaroli et al. [1] & ND & + & + & + & + & - & - & ND \\
\hline 2 & Shimao et al. [2] & + & ND & ND & + & + & + & ND & ND \\
\hline 3 & Damiani et al. [3] & + & + & + & + & + & - & - & ND \\
\hline 4 & [3] & + & + & + & + & + & - & - & ND \\
\hline 5 & {$[3]$} & + & + & + & + & + & - & - & ND \\
\hline 6 & {$[3]$} & + & + & + & + & + & - & - & ND \\
\hline 7 & {$[3]$} & + & + & + & + & + & - & - & ND \\
\hline 8 & Schmitt et al. [4] & ND & + & ND & - & + & - & - & - \\
\hline 9 & Coyne and Dervan [5] & ND & + & + & + & ND & ND & ND & ND \\
\hline 10 & Elster et al. [6] & ND & + & ND & + & + & - & - & - \\
\hline 11 & Peintinger et al. [7] & ND & + & + & + & + & - & - & ND \\
\hline 12 & Tanahashi et al. [8] & + & - & ND & - & ND & - & - & - \\
\hline 13 & Chang et al. [9] & ND & + & + & + & + & - & - & ND \\
\hline 14 & Choh et al. [10] & ND & ND & ND & ND & ND & ND & ND & ND \\
\hline 15 & Present case & + & + & + & + & + & - & - & - \\
\hline
\end{tabular}

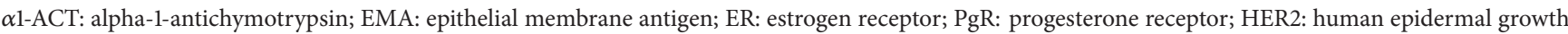
factor receptor 2; ND: not done.

levels. The tumor in this case was an infiltrating solid, trabecular, and microglandular pattern and, in most ACC, the tumor cells were immunohistochemically positive for amylase, lysozyme, $\alpha 1 \mathrm{ACT}$, S-100 protein, and EMA but were negative for estrogen receptor, progesterone receptor, and HER2 protein (Table 2).

In general, breast carcinoma lacking HER2 and the estrogen and progesterone receptors (triple-negative breast cancer TNBC) is more aggressive than other disease subtypes $[12,13]$. In contrast, ACC of the salivary glands is said to be a low-grade malignant neoplasm [14-16]. Therefore, it seems that ACC of the breast has characteristics similar to those of salivary gland, even if it is of the TNBC subtype. Although 1 patient was previously reported to have died as a result of this tumor type, standard adjuvant chemotherapy for breast cancer might not be always necessary. Several 


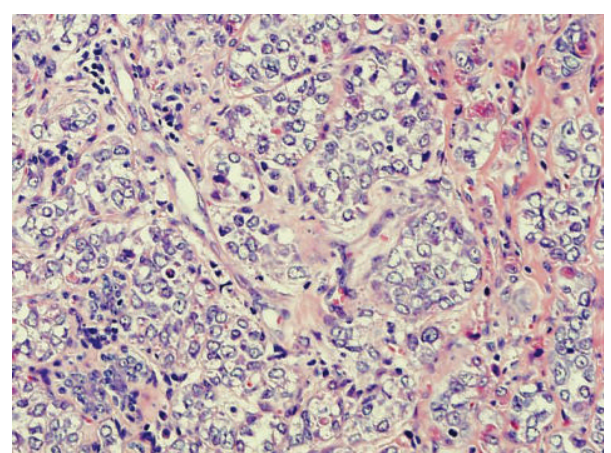

(a)

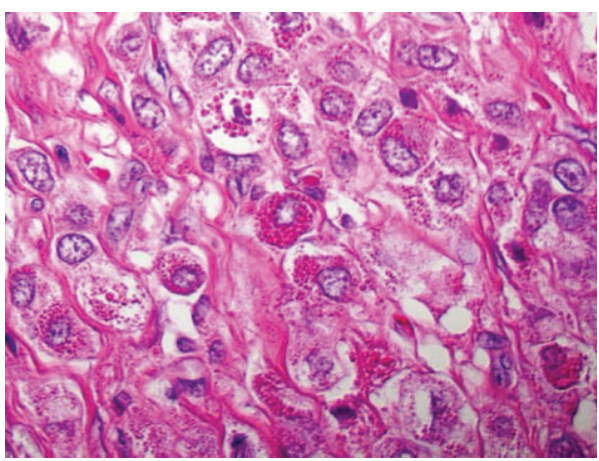

(c)

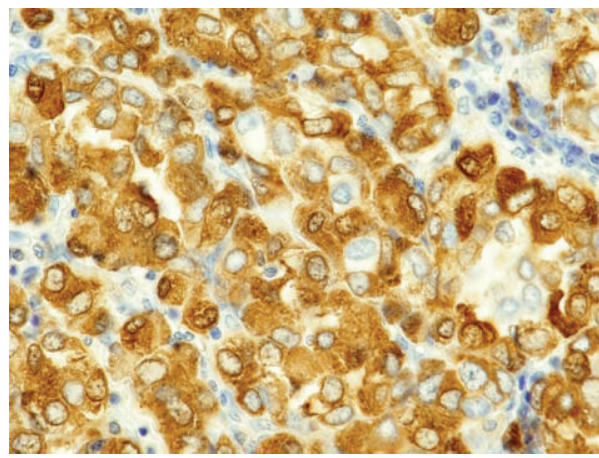

(e)

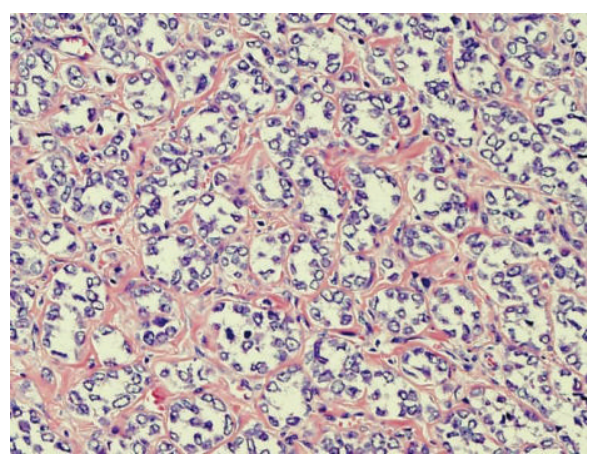

(b)

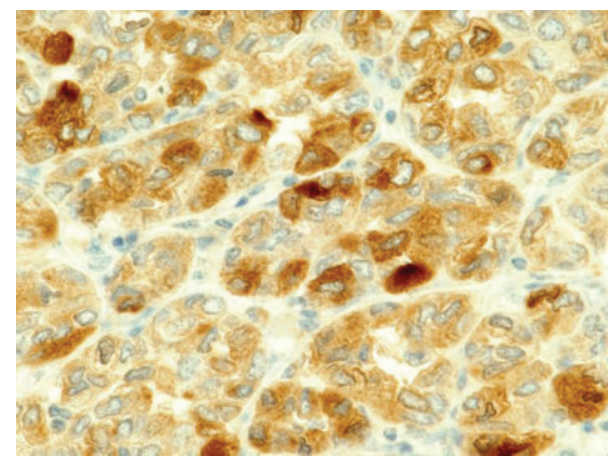

(d)

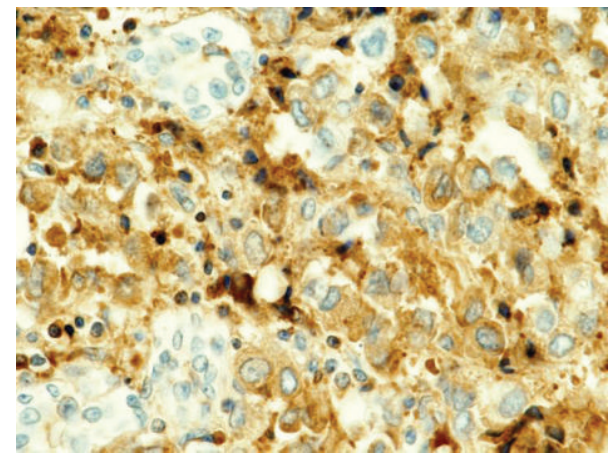

(f)

FIGURE 4: Microscopic findings showed that the tumor had an infiltrative growth pattern with a combination of solid (a), trabecular, and microglandular (b) features. Many of the tumor cells had clear cytoplasm containing large, coarse, and bright red granules which resemble acinar cells of the salivary glands (c). Immunohistochemical staining showed that most of the tumor cells stained strongly for amylase (d), lysozyme (e), and $\alpha 1 \mathrm{ACT}$ (f).

studies have reported that sporadic TNBC shares clinical and pathological features with hereditary BRCA1-related breast cancers [17-20], and, more recently, a case of a BRCA1 mutation carrier with an ACC of the breast was reported [21]. Therefore, further studies are necessary to determine the optimal therapeutic strategy for these tumors.

In summary, ACC of the breast is a rare variant of breast carcinoma that has been suggested to have a good prognosis even though it is often of the TNBC subtype. Currently, there are no characteristic diagnostic imaging findings for this disease, and immunohistochemical examination is important in making an accurate diagnosis. Further studies are needed to elucidate the biological characteristics of ACC of the breast.

\section{Conflict of Interests}

The authors declare that there is no conflict of interests regarding the publication of this paper.

\section{References}

[1] F. Roncaroli, J. Lamovec, A. Zidar, and V. Eusebi, "Acinic celllike carcinoma of the breast," Virchows Archiv, vol. 429, no. 1, pp. 69-74, 1996.

[2] K. Shimao, S. Haga, T. Shimizu et al., "Acinic cell adenocarcinoma arising in the breast of a young male: a clinicopathological, immunohistochemical and ultrastructural study," Breast Cancer, vol. 5, no. 1, pp. 77-81, 1998. 
[3] S. Damiani, G. Pasquinelli, J. Lamovec, J. L. Peterse, and V. Eusebi, "Acinic cell carcinoma of the breast: an immunohistochemical and ultrastructural study," Virchows Archiv, vol. 437, no. 1, pp. 74-81, 2000.

[4] F. C. Schmitt, C. A. Ribeiro, S. Alvarenga, and J. M. Lopes, "Primary acinic cell-like carcinoma of the breast: a variant with good prognosis?” Histopathology, vol. 36, no. 3, pp. 286-289, 2000.

[5] J. D. Coyne and P. A. Dervan, "Primary acinic cell carcinoma of the breast," Journal of Clinical Pathology, vol. 55, no. 7, pp. 545$547,2002$.

[6] E. A. Elster, J. Markusic, R. Ball et al., "Primary acinic cell carcinoma of the breast," American Surgeon, vol. 68, no. 11, pp. 993-995, 2002.

[7] F. Peintinger, S. Leibl, R. Reitsamer, and F. Moinfar, "Primary acinic cell carcinoma of the breast: a case report with long-term follow-up and review of the literature," Histopathology, vol. 45, no. 6, pp. 645-648, 2004.

[8] C. Tanahashi, S. Yabuki, N. Akamine, Y. Yatabe, and S. Ichihara, "Pure acinic cell carcinoma of the breast in an 80-year-old Japanese woman," Pathology International, vol. 57, no. 1, pp. 4346, 2007.

[9] E. D. Chang, E. J. Lee, A. W. Lee, J. S. Kim, and C. S. Kang, "Primary acinic cell carcinoma of the breast: a case report with an immunohistochemical and ultrastructural studies," Journal of Breast Cancer, vol. 14, no. 2, pp. 160-164, 2011.

[10] C. T. Choh, V. Komar, and S. P. Courtney, "Primary acinic cell carcinoma of the breast: a rare lesion with good prognosis," The Breast Jornal, vol. 18, no. 6, pp. 610-611, 2012.

[11] A. Matoso, S. E. Easley, D. R. Gnepp, and S. Mangray, "Salivary gland acinar-like differentiation of the breast: correspondence," Histopathology, vol. 54, no. 2, pp. 262-263, 2009.

[12] K. R. Bauer, M. Brown, R. D. Cress, C. A. Parise, and V. Caggiano, "Descriptive analysis of estrogen receptor (ER)negative, progesterone receptor (PR)-negative, and HER2negative invasive breast cancer, the so-called triple-negative phenotype: a population-based study from the California Cancer Registry," Cancer, vol. 109, no. 9, pp. 1721-1728, 2007.

[13] O. Gluz, C. Liedtke, N. Gottschalk, L. Pusztai, U. Nitz, and N. Harbeck, "Triple-negative breast cancer: current status and future directions," Annals of Oncology, vol. 20, no. 12, pp. 19131927, 2009.

[14] C. M. Eneroth, P. A. Jakobsson, and C. Blanck, "Acinic cell carcinoma of the parotid gland," Cancer, vol. 19, no. 12, pp. 1761$1772,1966$.

[15] H. T. Hoffman, L. H. Karnell, R. A. Robinson, J. A. Pinkston, and H. R. Menck, "National Cancer Data Base report on cancer of the head and neck: acinic cell carcinoma," Head and Neck, vol. 21, no. 4, pp. 297-309, 1999.

[16] H. Luukkaa, P. Klemi, I. Leivo et al., "Salivary gland cancer in Finland 1991-96: an evaluation of 237 cases," Acta OtoLaryngologica, vol. 125, no. 2, pp. 207-214, 2005.

[17] F. Eisinger, J. Jacquemier, C. Charpin et al., "Mutations at BRCA1: the medullary breast carcinoma revisited," Cancer Research, vol. 58, no. 8, pp. 1588-1592, 1998.

[18] J. N. Marcus, P. Watson, D. L. Page et al., "Hereditary breast cancer: pathobiology, prognosis, and BRCA1 and BRCA2 gene linkage," Cancer, vol. 77, no. 4, pp. 697-709, 1996.

[19] S. E. Karp, P. N. Tonin, L. R. Begin et al., "Influence of BRCA1 mutations on nuclear grade and estrogen receptor status of breast carcinoma in Ashkenazi Jewish women," Cancer, vol. 80, no. 3, pp. 435-441, 1997.
[20] L. C. Verhoog, C. T. M. Brekelmans, C. Seynaeve et al., "Survival and tumour characteristics of breast-cancer patients with germline mutations of BRCA1," Lancet, vol. 351, no. 9099, pp. 316-321, 1998.

[21] C. B. Ripamonti, M. Colombo, P. Mondini et al., "First description of an acinic cell carcinoma of the breast in a BRCA1 mutation carrier: a case report," BMC Cancer, vol. 13, article 46, 2013. 


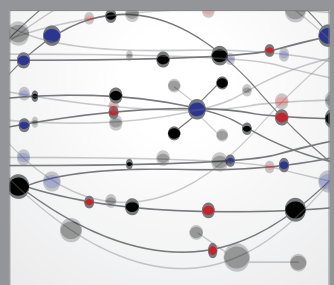

The Scientific World Journal
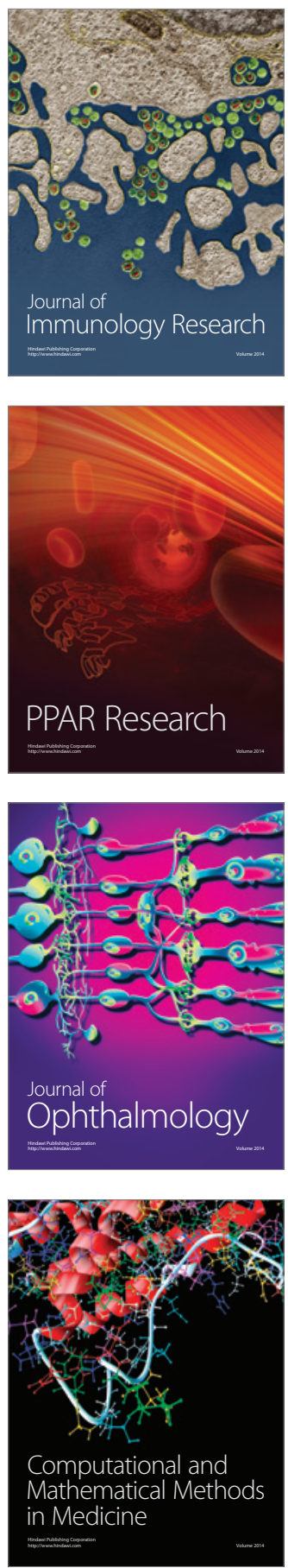

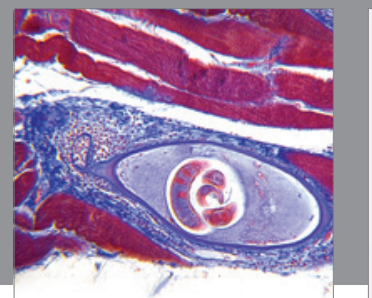

Gastroenterology

Research and Practice
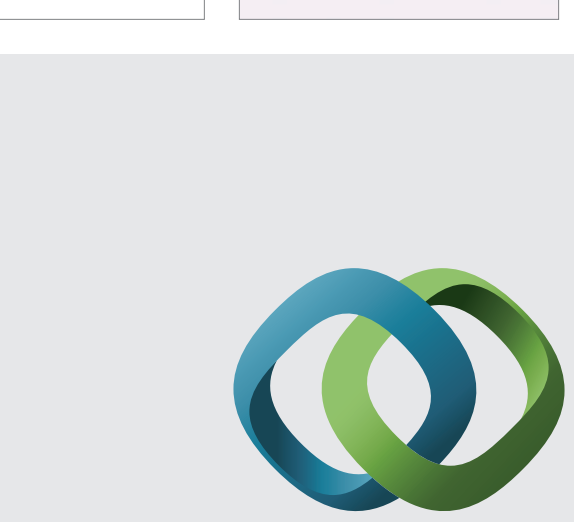

\section{Hindawi}

Submit your manuscripts at

http://www.hindawi.com
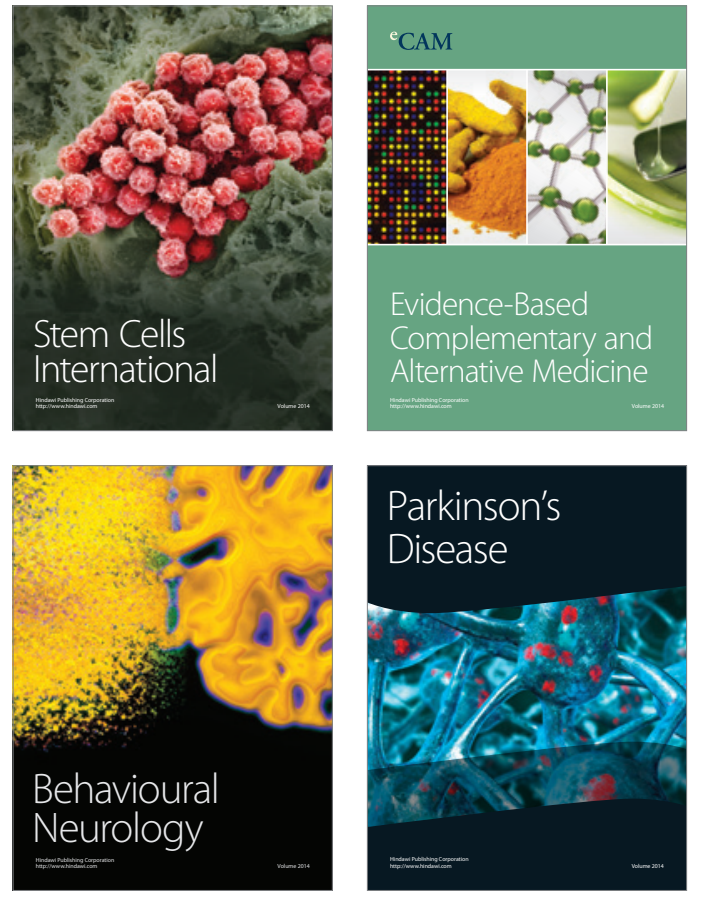
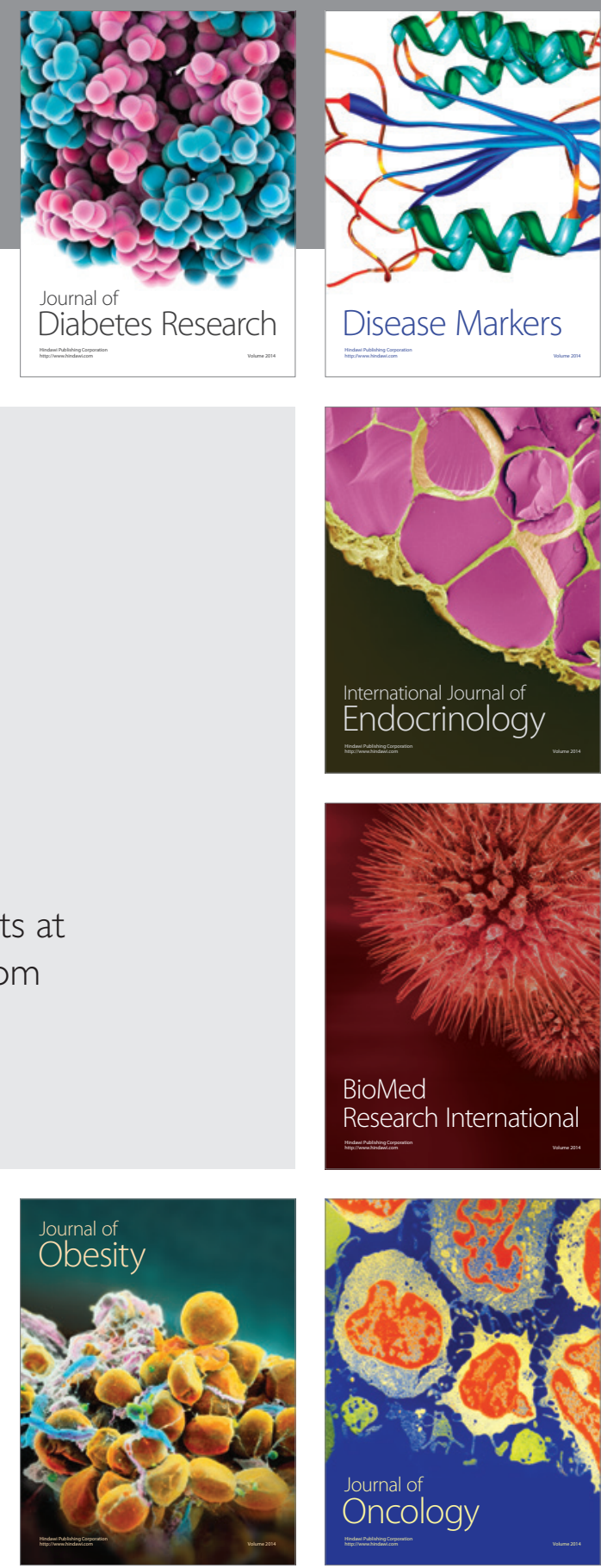

Disease Markers
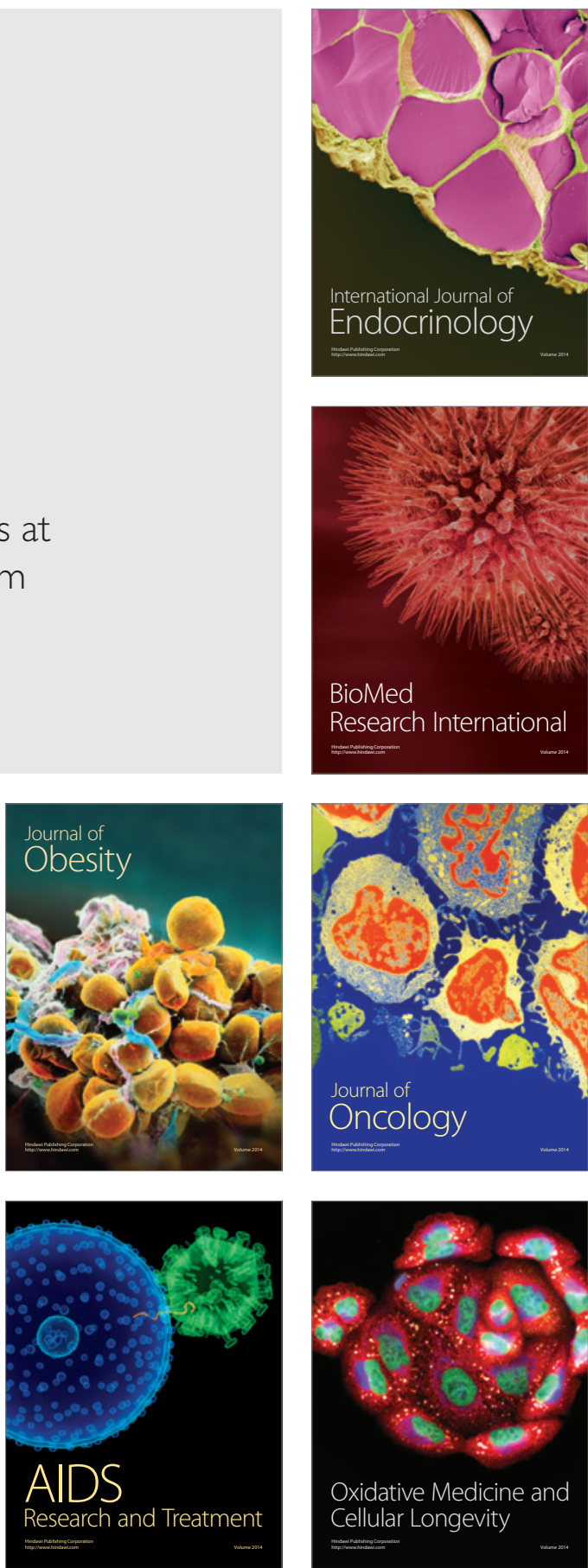